\title{
Educational Technologies for Child Health Promotion: An Integrative Literature Review
}

\author{
Rosalia Daniela Medeiros da Silva ${ }^{{ }^{*}}$, Estela Maria Leite Meirelles Monteiro ${ }^{2}$, \\ Luciana Pedrosa Leal ${ }^{3}$, Francisca Márcia P. Linhares³, Luciane Soares de Lima² \\ ${ }^{1}$ Graduate Child and Adolescent Health Program at UFPE, Recife, Brazil \\ ${ }^{2}$ Graduate Nursing Program and Graduate Child and Adolescent Health Program at UFPE, Recife, Brazil \\ ${ }^{3}$ Nursing Department and Graduate Nursing Program at UFPE, Recife, Brazil \\ Email: *rosaliadaniela@hotmail.com
}

Received 18 July 2016; accepted 22 August 2016; published 25 August 2016

Copyright (C) 2016 by authors and Scientific Research Publishing Inc.

This work is licensed under the Creative Commons Attribution International License (CC BY).

http://creativecommons.org/licenses/by/4.0/

(c) (i) Open Access

\begin{abstract}
The use of educational technology focused on child health promotion requires theoretical-methodological foundations to support aspects related to the growth and psychomotor development stage, articulating knowledge and healthy habits as early as possible. This article is an integrative review to investigate the educational technologies used in health education actions to promote child health. The databases LILACS, MEDLINE, BDENF, PUBMED, CINAHL, and in the Virtual library Cochrane Library and SciELO were consulted. Thirteen articles were analyzed. The educational technologies have been employed to promote child health promotion actions and have contributed to the achievement of long-lasting results. The actions happen predominantly in the school context and light, light-hard and hard technologies are used. The association between light and hard technology obtained better results.
\end{abstract}

\section{Keywords}

Health Education, Health Promotion, Educational Technology, Child

\section{Introduction}

The technologies based on health promotion have been described as a new and promising paradigm in health, due to the range of its theoretical-methodological approaches, constituting its complexity and main conceptual

*Corresponding author.

How to cite this paper: da Silva, R.D.M., Monteiro, E.M.L.M., Leal, L.P., Linhares, F.M.P. and de Lima, L.S. (2016) Educational Technologies for Child Health Promotion: An Integrative Literature Review. Health, 8, 1104-1111.

http://dx.doi.org/10.4236/health.2016.811115 
bases, which are: the emphasis on the integrality of care and on the prevention of health problems; the social commitment to quality of life and the adoption of participation as process planning and assessment [1].

Health Promotion supports the reorganization of health work, so that it constitutes a form of organized social response to the health problems and needs of a given population, associated with an expanded, positive and complex view of health, which represents the concrete possibility of breaking with the biomedical paradigm to propose a new form of intervention in the health area [1] [2]. In the reorganization of health work, it is fundamental to attend to the population's demands and needs from a health promotion perspective. In this context, the technologies are tools capable of articulating innovative strategies that aim to equip the population's health actions.

According to Nietsche [3], the conception of technology has been emphatically used in daily life, but often wrongly, as it has only been conceived as a product, a machine, something concrete. Technology corresponds to the result of processes that are put in practice based on daily experience and research, with a view to developing a set of scientific knowledge to construct products, whether material or not, with a view to provoking interventions in a given practical situation. This entire process should be assessed and systematically controlled. In the health sphere, the technologies are subdivided into care, management and education.

Educational technology is a systematic set of scientific knowledge that permits planning, execution, control and monitoring, involving the entire formal and informal education process. To apply the educational technology, whether process or product-related, the educator (health professional) needs to serve as a facilitator of the teaching-learning process and the student (client) as a participating subject in this process, involved in a creative conscience of sensitivity and creativity in the search for personal and professional growth [3].

The use of educational technology focused on child health promotion requires a theoretical-methodological background that supports aspects of the growth and psychomotor development stage, articulating knowledge and healthy habits as early as possible, and also minimizing physical and emotional risk situations. In this context, the objective in this study was to investigate the educational technologies used in health education actions in child health promotion.

\section{Materials and Methods}

An integrative review was undertaken, which consists in the analysis of relevant studies, in a systematic and organized manner that permits the synthesis of current knowledge on a given theme, besides appointing knowledge gaps that need to be completed [4] [5].

To put this review in practice, six steps recommended by Mendes [4] were followed: 1) identification of the theme and elaboration of the research question; 2) establishment of inclusion and exclusion criteria; 3) definition of information to be extracted from the selected studies; 4) assessment of the studies included in the integrative review; 5) interpretation of the results; 6) presentation of the review.

The guiding question elaborated for this study was: what educational technologies have been used for health education actions in child health promotion? The following inclusion criteria were established: articles published between 2008 and 2013 in English, Portuguese or Spanish, with a view to finding current evidence in the field of educational technology for children. The exclusion criteria were: technical documents, annals, editorials, congress abstracts, comments, reflection articles, experience report, dissertations, theses and articles that were not in accordance with the research question. The research was undertaken between October and November 2013.

The bibliographic survey was undertaken in the databases Latin American and Caribbean Health Science Literature (LILACS), International Health Science Literature (MEDLINE), Nursing Databases (BDENF), US National Library of Medicine of the National Institutes of Health (PUBMED), Cumulative Index to Nursing and Allied Health Literature (CINAHL), in the Virtual Cochrane Library and Scientific Electronic Library Online (SciELO). The Descriptors in Health Sciences (DeCS) and their respective translations were: Health Education, Educational technology, Child, Health promotion and Child health, in English, Portuguese and Spanish, according to the database. The combinations were made through the use of the Boolean operator "AND" for the combination in five triads among the descriptors.

The crossing of the descriptors resulted in a total number of 2515 articles, 17 of which came from SciELO, 71 from LILACS, 989 from MEDLINE, 865 from CINAHL, 373 from Cochrane, 200 from Pubmedand none from BDENF. The articles were analyzed and 2490 were excluded because they did not comply with the inclusion criteria and/or did not adapt to the research question; 25 articles were selected, 11 of which were excluded be- 
cause they were repeated and one because it did not present the final study results. This resulted in final sample of 13 articles.

The 13 articles selected were fully read and the criteria and methods employed in their development were critically assessed to determine their methodological validity. None of the articles were excluded after this evaluation [4]. To extract the data regarding the research question, an instrument was used that had been adapted from the model proposed by Pompeo [6], with a view to summarizing the information orderly. Information was collected on the database, journal, academic background of the authors and country of origin, language, year of publication, institution where the study was undertaken, type of study, evidence level, educational technology used, results and conclusion.

The evidence level of the studies was attributed according to the classification by Stetler [7] with level Iresults of meta-analysis of controlled and randomized clinical studies; level II—experimental studies; level III— quasi-experimental research; level IV—descriptive study or with a qualitative approach; level V—case or experience reports and level VI-expert opinions or based on standards or laws.

The types of educational technologies used in the studies were analyzed based on the definition of technologies by Merhy and Onocko [8], in which "light technologies" refer to the relations, welcoming, bonding and service management; "light-hard technologies" correspond to the well-structured knowledge that guides the work, standards, protocols and the knowledge produced in the different knowledge areas; and "hard technologies" refer to the machinery, equipment, instruments and constitute well-structured and materialized knowledge and know-how.

\section{Results}

Among the articles included in this review, three were published in 2008, four in 2009, one in 2011, four in 2012 and one in 2013, being nine in English and four in Portuguese. The impact factor of ten journals in which the studies were published ranged between 0.09 and 8.24. For the other three, this information was not located. The evidence levels of the studies were: four level II, six level III and three level IV.

Table 1 displays a synthesis of the papers included in this integrative review.

\section{Discussion}

The critical analysis of the publications in the light of the theoretical framework by Merhy and Onocko (2002) [8] regarding the classification of the technologies used showed that light, light-hard and hard technologies were used. Among the studies, 10 predominantly used light-hard technologies as a strategy in the educational actions [9]-[13] [16]-[20], including: puppet theater, comics, dynamics, drawing contests, dance classes and practical demonstration. Three studies predominantly applied hard technologies for the sake of child health promotion [14] [15] [21], including: computer program, radio program and multimedia. The association of light, light-hard and hard technologies was also present.

The studies that used the hard technologies associated with light technology obtained better results, like in the case when a multimedia program was used to promote knowledge on cerebrovascular accident [21], in which the children who developed activities with relatives better apprehended new knowledge. The same result was observed in the study that used the daily radio program [15] transmitted at the school and demonstrated that, when a moment of interaction with the teacher took place after the exhibition of the program, including discussion about the theme, better results were obtained in terms of knowledge acquisition about health. A similar result was found in the study that used the computer program associated with the teacher's class [14].

The use of the hard technology only, without any intention, without interaction through the light technology, does not seem to produce such favorable results in the health promotion actions. The health professionals need and should use technological resources, mainly in child health promotion, with a view to attractive interventions that achieve the proposed objectives. Nevertheless, it should be taken into account that the computer will never replace the human essence and technological advances should be used to rescue that essence [22].

Among the selected studies, four used practical experience associated with theoretical knowledge to promote the children's effective participation, resulting in positive outcomes that continued for months after the interventions, such as eating habits, postural and oral health changes [10] [16] [17] [20].

Another important finding refers to health professionals' interdisciplinary actions, and also in partnership with teachers [18]-[20], favoring the promotion of child health. In a multicenter study, health professionals in inter 
Table 1. Study characteristics and findings.

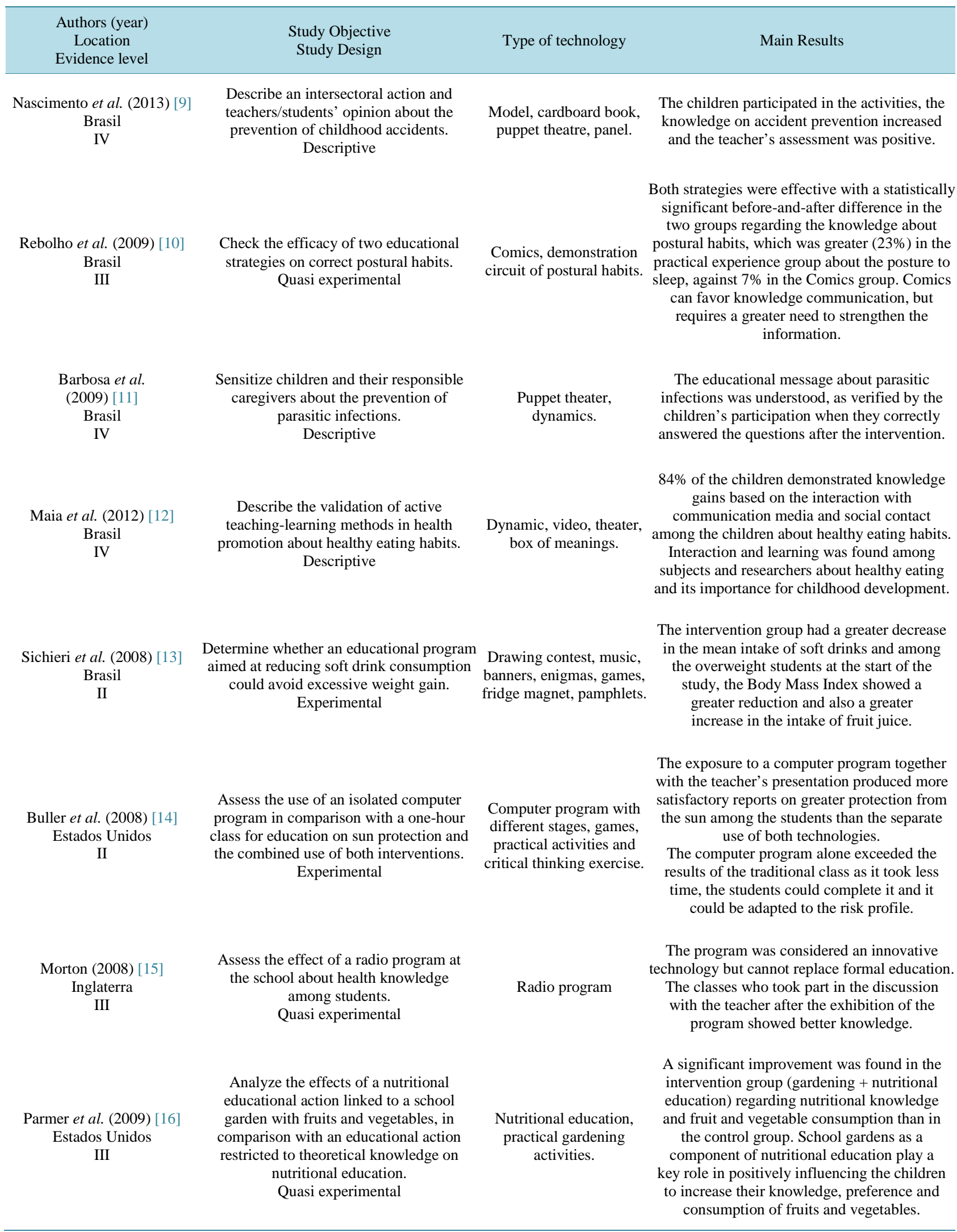




\section{Continued}

\begin{tabular}{|c|c|c|c|}
\hline $\begin{array}{c}\text { Makuch et al. (2011) [17] } \\
\text { Alemanha } \\
\text { III }\end{array}$ & $\begin{array}{l}\text { Compare the efficacy of the artificial } \\
\text { brushing model and individual modeling } \\
\text { to teach correct brushing. } \\
\text { Quasi experimental }\end{array}$ & $\begin{array}{l}\text { Amplified prototype } \\
\text { dental arch, teeth model } \\
\text { in the mouth of the animal } \\
\text { puppet, practicing } \\
\text { brushing in front of } \\
\text { the mirror and adult } \\
\text { demonstrating. }\end{array}$ & $\begin{array}{l}\text { Differences were found among the four types } \\
\text { of models. 75\% of the children from the group } \\
\text { with demonstration by an adult recognized the } \\
\text { appropriate positioning and movements for } \\
\text { brushing. A combination between assisted } \\
\text { brushing and a simultaneous demonstration in } \\
\text { front of a mirror showed to be the most } \\
\text { effective approach. }\end{array}$ \\
\hline $\begin{array}{c}\text { Hogg et al. (2012) [18] } \\
\text { Estados Unidos } \\
\text { III }\end{array}$ & $\begin{array}{c}\text { Determine whether an intensive post-school } \\
\text { dance course and an education program } \\
\text { and a lifestyle education program reduces } \\
\text { the risk factors for cardiac illnesses, } \\
\text { type } 2 \text { diabetes mellitus, and improves } \\
\text { the lifestyle choices. } \\
\text { Quasi experimental }\end{array}$ & $\begin{array}{l}\text { Dance classes, } \\
\text { interactive seminar. }\end{array}$ & $\begin{array}{l}\text { The eating habits improved, with increases in } \\
\text { the consumption of foods rich in calcium, fruits, } \\
\text { vegetables, whole grains and reduction of soft } \\
\text { drink intake. Physical exercise increased by } \\
40 \% \text {, the time spent watching TV and computer } \\
\text { games by } 30 \% \text {, and both continued after six } \\
\text { months. The results were maintained after six } \\
\text { months of follow-up. } \\
\text { The study also showed a positive impact on } \\
\text { the Body Mass Index and body composition } \\
\text { among obese and overweight children. }\end{array}$ \\
\hline $\begin{array}{c}\text { Devault et al. (2009) [19] } \\
\text { Estados Unidos } \\
\text { II }\end{array}$ & $\begin{array}{l}\text { Assess the impact of “It's all about Kids” } \\
\text { on knowledge, attitudes and behaviors } \\
\text { related to nutrition. } \\
\text { Experimental }\end{array}$ & $\begin{array}{l}\text { Class using hand's on } \\
\text { with fruits and vegetables, } \\
\text { bingo, practical activities. }\end{array}$ & $\begin{array}{l}\text { The knowledge on foods with higher fat } \\
\text { contents improved, the attitudes towards the } \\
\text { choice of healthy and less fatty foods changed } \\
\text { positively. There was a trend to reduce } \\
\text { the consumption of fatty milk. }\end{array}$ \\
\hline $\begin{array}{c}\text { Macnab \& Kasangaki } \\
\text { (2012) [20] } \\
\text { Canadá/África } \\
\text { II }\end{array}$ & $\begin{array}{l}\text { Assess the effect of an oral health } \\
\text { program in a school that promotes } \\
\text { health through different strategies for } \\
\text { oral health promotion in children. } \\
\text { Experimental }\end{array}$ & $\begin{array}{l}\text { Audiovisual resources, } \\
\text { music, games, practical } \\
\text { demonstration, tooth } \\
\text { model. }\end{array}$ & $\begin{array}{l}\text { The frequency of teeth brushing improved, } \\
\text { the use of inappropriate alternatives for } \\
\text { toothpaste stopped (soap, ashes, carbon and } \\
\text { sand). The children's oral health considerably } \\
\text { improved and they shared the knowledge } \\
\text { with their parents and siblings. The teachers' } \\
\text { assessment demonstrated positive benefits } \\
\text { of the school turning into a health promotion } \\
\text { institution and included greater knowledge } \\
\text { about health. A drop in the absence of students } \\
\text { due to pain or emergency dental treatment } \\
\text { was evidenced. The oral health model } \\
\text { described offers simple. }\end{array}$ \\
\hline $\begin{array}{l}\text { Williams et al. (2012) [21] } \\
\text { Estados Unidos } \\
\text { III }\end{array}$ & $\begin{array}{l}\text { Assess the effect of the Hip Hop Stroke, a } \\
\text { multimedia musical, about cerebrovascular } \\
\text { accident based on the school intervention } \\
\text { in high-risk minority communities, in } \\
\text { long-term learning of knowledge about } \\
\text { cerebrovascular accede } \\
\text { nt. Quasi-experimental }\end{array}$ & $\begin{array}{l}\text { Multimedia with music, } \\
\text { cartoons, videogame, } \\
\text { comics, theater and quiz. }\end{array}$ & $\begin{array}{l}\text { And easily adoptable strategies to establish } \\
\text { more health promotion schools. }\end{array}$ \\
\hline
\end{tabular}

professional and inter sectoral cooperation with teachers developed education and health promotion actions in Malawi, Zambia, and the United States and obtained positive results in terms of health care information, development of long-term sustainable partnerships and greater awareness regarding the use of resources for global health education [23]. According to Pereira and Oliveira [2], interdisciplinarity requires coordinated work with shared objectives, in an integrated and converging manner, shared among different knowledge branches. Interdisciplinary work favors the apprehension of multiple perspectives, contributes to enhance interventions and understand complex issues, and also contributes to the acknowledgement of and coping with health-related problems [24].

The most discussed theme in the studies analyzed was healthy eating habits [12] [13] [16] [18] [19], which supports the fact that the high overweight levels among children currently represents a risk factor of global concern for cardiovascular diseases. This concern has motivated different studies to analyze the relation between healthy habits and physical exercise [25], develop educational actions that promote correct food choices [13] 
and also stimulate fruit and vegetable consumption as a part of the diet [26].

All studies in the final sample were developed in the school context, except one [11] developed in primary care. One important reflection is that the hospital environment can also be considered a space to promote educational activities for the purpose of health promotion, especially for children and adolescents with chronic illnesses. The use of educational technologies can favor the establishment of partnerships among children, relatives and health teams, an important premise to achieve good results [27]. According to Paula [28], in the hospital environment, technology is an instrument of social inclusion, grants the children and adolescents freedom and overcoming of challenges in this environment filled with limitations, at the same time as it offers different interactive possibilities.

\section{Conclusions}

The educational technologies have been employed to promote child health promotion actions and have contributed to the achievement of long-lasting results. The actions happen predominantly in the school context and light technologies are used, such as interaction with teachers, health professionals and family members during the health education actions; mild-hard technologies such as puppet theater, dynamics, comics, drawing contests and practical demonstration and hard technologies like computer and multimedia programs.

This review showed that the association between light and hard technology obtained better results, which may appoint the familiarity of the current generation's children and adolescents with technologies, as they live in different social and pedagogical environments, with access to several information sources.

As part of the children's daily life, technology can be used as a tool to disseminate health knowledge. Nevertheless, its use does not waive interaction with health professionals, teachers and relatives, considering that, in the teaching-learning process, the technologies need to be used intentionally, so that the objectives can be achieved.

\section{Acknowledgements}

This research was supported by master grant (Rosalia Daniela Medeiros da Silva), in the Graduate Nursing Program at UFPE, Recife, Brazil, CAPES (Coordinator for the Improvement of the Higher Level Personnel)—Pro Education in Health, Brazil.

\section{References}

[1] Chiesa, A.M., Fracolli, L.A., Veríssimo, M.L.O.R., Zoboli, E.L.C.P., Ávila, L.K. and Oliveira, A.A.P. (2009) A construção de tecnologias de atenção em saúde com base na promoção da saúde. Revista da Escola de Enfermagem da USP, 43, 1352-1357. http://dx.doi.org/10.1590/s0080-62342009000600036

[2] Pereira, C.P. and Oliveira, M.A.C. (2013) The Work of Community Health Agents in Health Promotion: An Integrative Literature Review. Revista Brasileira de Enfermagem, 66, 412-419. http://dx.doi.org/10.1590/S0034-71672013000300017

[3] Nietsche, E.A., Backes, V.M.S., Colomé, C.L.M., Ceratti, R.N. and Ferraz, F. (2005) Tecnologias educacionais, assistenciais e gerenciais: Uma reflexão a partir da concepção dos docentes de enfermagem. Revista Latino-Americana de Enfermagem, 13, 344-352. http://www.scielo.br/pdf/rlae/v13n3/v13n3a09.pdf http://dx.doi.org/10.1590/S0104-11692005000300009

[4] Mendes, K.D.S., Silveira, R.C.C.P. and Galvão, C.M. (2008) Revisão integrativa: Método de pesquisa para a incorporação de evidências na saúde e na enfermagem. Texto \& Contexto Enfermagem, 17, 758-764. http://dx.doi.org/10.1590/S0104-07072008000400018

[5] Polit, D.F. and Beck, C.T. (2006) Using Research in Evidence-Based Nursing Practice. Essentials of Nursing Research. Methods, Appraisal and Utilization, Lippincott Williams \& Wilkins, Philadelphia, 457-494.

[6] Pompeo, D.A. (2007) Diagnóstico de enfermagem náusea em pacientes no período pós-operatório imediato: Revisão integrativa da literatura. 185f. Dissertação. (Mestrado em Enfermagem)-Escola de Enfermagem de Ribeirão Preto, Universidade de São Paulo, Ribeirão Preto. http://www.teses.usp.br/teses/disponiveis/22/.../DanieleAlcalaPompeo.pdf\%E2\%80\%8E

[7] Stetler, C.B., Brunell, M., Giuliano, K.K., Morsi, D., Prince, L. and Newell-Stokes, V. (1998) Evidence-Based Practice and the Role of Nursing Leadership. Journal of Nursing Administration, 28, 45-53.

http://www.ncbi.nlm.nih.gov/pubmed/9709696 http://dx.doi.org/10.1097/00005110-199807000-00011 
[8] Merhy, E.E. and Onocko, R. (2002) Em busca de ferramentas analisadoras das tecnologias em saúde: A informação e o dia a dia de um serviço, interrogando e gerindo trabalho em saúde. Agir em saúde: Um desafio para o público, 2nd Edition, Hucitec, São Paulo, 113-150.

[9] Nascimento, E.N.,Gimeniz-Paschoal, S.R., Sebastião, L.T. and Ferreira, N.P. (2013) Inter-Sector Actions to Prevent Accidents in Children Education: Teacher's Assessments and Students' Knowledge. Journal of Human Growth and Development, 23, 99-106.

[10] Rebolho, M.C.T., Casarotto, R.A. and João, S.M.A. (2009) Estratégias para ensino de hábitos posturais em crianças: História em quadrinhos versus experiência prática. Fisioterapia e Pesquisa, 16, 46-51. http://dx.doi.org/10.1590/S1809-29502009000100009

[11] Barbosa, L.A., Sampaio, A.L.A., Melo, A.L.A., Macedo, A.P.N. and Machado, M.F.A.S. (2009) A educação em saúde como instrumento na prevenção de parasitoses. RBPS, 22, 272-282. http://dx.doi.org/10.5020/18061230.2009.p272

[12] Maia, E.R., Junior, J.F.L., Pereira, J.S., Eloi, A.C., Gomes, C.C. and Nobre, M.M.F. (2012) Validação de metodologias ativas de ensino-aprendizagem na promoção da saúde alimentar infantil. Rev. Nutr., 25, 79-88. http://dx.doi.org/10.1590/S1415-52732012000100008

[13] Sichieri, R., Paula, A.T., Souza, R.A. and Veiga, G.V. (2009) School Randomised Trial on Prevention of Excessive Weight Gain by Discouraging Students from Drinking Sodas. Public Health Nutrition, 12, 197-202. http://dx.doi.org/10.1017/S1368980008002644

[14] Buller, M.K., Kane, I.L., Martin, R.C., Giese, A.J., Cutter, G.R., Saba, L.M., et al. (2008) Randomized Trial Evaluating Computer-Based Sun Safety Education for Children in Elementary School. Journal of Cancer Education, 23, 74-79. http://dx.doi.org/10.1080/08858190701818267

[15] Morton, J.L. (2008) “I Feel Good!” a Weekly Wellness Radio Broadcast for Elementary School Children. The Journal of School Nursing, 24, 83-87. http://dx.doi.org/10.1177/10598405080240020601

[16] Parmer, S.M., Salisbury-Glennon, J., Shannon, D. and Struempler, B. (2009) School Gardens: An Experiential Learning Approach for a Nutrition Education Program to Increase Fruit and Vegetable Knowledge, Preference, and Consumption among Second-Grade Students. Journal of Nutrition Education and Behavior, 41, 212-272. http://dx.doi.org/10.1016/j.jneb.2008.06.002

[17] Makuch, A., Reschke, K. and Rupf, S. (2011) Effective Teaching of Tooth-Brushing to Preschool Children. Journal of Dentistry for Children, 78, 9-12.

[18] Hogg, J., Diaz, A., Del Cid, M., Mueller, C., Lipman, E.G., Cheruvu, S., et al. (2012) An After-School Dance and Lifestyle Education Program Reduces Risk Factors for Heart Disease and Diabetes in Elementary School Children. Journal of Pediatric Endocrinology and Metabolism, 25, 509-516. http://dx.doi.org/10.1515/jpem-2012-0027

[19] Devault, N., Kennedy, T., Hermann, J., Mwavita, M., Rask, P. and Jaworsky, A. (2009) It’s All about Kids: Preventing Overweight in Elementary School Children in Tulsa, OK. Journal of the American Dietetic Association, 109, 680-687. http://dx.doi.org/10.1016/j.jada.2008.12.021

[20] Macnab, A. and Kasangaki, A. (2012) "Many Voices, One Song”: A Model for an Oral Health Programme as a First Step in Establishing a Health Promoting School. Health Promotion, 27, 63-73. http://dx.doi.org/10.1093/heapro/dar039

[21] Williams, O., Desorbo, A., Noble, J., Shaffer, M. and Gerin, W. (2012) Long-Term Learning of Stroke Knowledge among Children in a High-Risk Community. Neurology, 79, 802-806. http://dx.doi.org/10.1212/WNL.0b013e3182661f08

[22] Fonseca, L.M.M., Silva, M.A.I., Mello, D.F., Leite, A.M., Lima, R.A.G. and Scochi, C.G.S. (2011) Tecnologia educacional em saúde: contribuições para a enfermagem pediátrica e neonatal. Escola Anna Nery, 15, 190-196. http://www.scielo.br/pdf/ean/v15n1/27.pdf http://dx.doi.org/10.1590/S1414-81452011000100027

[23] Wilson, L.L., Somerall, D., Theus, L., Rankin, S., Ngoma, C. and Chimwaza, A. (2014) Enhancing Global Health and Education in Malawi, Zambia, and the United States through and Interprofessional Global Health Exchange Program. Applied Nursing Research, 27, 97-103. http://dx.doi.org/10.1016/j.apnr.2013.06.002

[24] Bindler, R.C., Richardson, B., Daratha, K. and Wordell, D. (2012) Interdisciplinary Health Science Research Collaboration: Strengths, Challenges, and Case Example. Applied Nursing Research, 25, 95-100. http://dx.doi.org/10.1016/j.apnr.2010.06.004

[25] Harrington, S.A. (2013) Relationships of Objectively Measured Physical Activity and Sleep with BMI and Academic Outcomes in 8-Year-Old Children. Applied Nursing Research, 26, 63-70. http://dx.doi.org/10.1016/j.apnr.2013.02.001

[26] Long, J.D., Boswel, C., Rogers, T.J., Littlefield, L.A., Estep, G., Shriver, B.J., et al. (2013) Effectiveness of Cell Phones and Mypyramidtracker. gov to Estimate Fruit and Vegetable Intake. Applied Nursing Research, 26, 17-23. http://dx.doi.org/10.1016/j.apnr.2012.08.002

[27] Nogueira, P.C., Nagliate, P.C., Godoy, S., Rangel, E.M.L., Trevizan, M.A. and Mendes, I.A.C. (2013) Technology Use 
for Health Education to Caregivers: An Integrative Review of Nursing Literature. Applied Nursing Research, 26, 101104. http://www.sciencedirect.com/science/article/pii/S0897189713000050 http://dx.doi.org/10.1016/j.apnr.2013.01.004

[28] Paula, E.M.A.T. (2007) Crianças e adolescentes que voam em jaulas: A tecnologia promovendo a liberdade no hospital. Cadernos CEDES, 27, 319-334. http://dx.doi.org/10.1590/S0101-32622007000300005

\section{Submit or recommend next manuscript to SCIRP and we will provide best service for you:}

Accepting pre-submission inquiries through Email, Facebook, LinkedIn, Twitter, etc.

A wide selection of journals (inclusive of 9 subjects, more than 200 journals)

Providing 24-hour high-quality service

User-friendly online submission system

Fair and swift peer-review system

Efficient typesetting and proofreading procedure

Display of the result of downloads and visits, as well as the number of cited articles

Maximum dissemination of your research work

Submit your manuscript at: http://papersubmission.scirp.org/ 